certain deep partial-loss burns. S. Sevitt ${ }^{9}$ confirmed these findings in animal experiments, and the pin-prick test has now been established as a useful clinical guide. ${ }^{4}$ Another group of tests has been based on survival of vascular supply. T. Gibson and A. Brown ${ }^{10}$ described the use of a dye, Kiton fast green, given intravenously as a method for distinguishing between areas of partial- and full-thickness loss. This was further elaborated by $M$. N. Tempest, ${ }^{11}$ who used disulphine blue. Areas of partial-thickness loss are stained by the dye whereas those of whole-thickness loss remain uncoloured. Another variant on this method was described by J. A. Dingwall, ${ }^{12}$ who used intravenous fluorescein and was able to demonstrate similar differences of staining by observation in ultra-violet light.

A more recently developed test depends on the differences of surface temperature of burns of different depths. A. V. Forage ${ }^{13} 14$ has described detailed studies of a large series of injuries, many of them scalds of chests in children, in which measurements of surface temperature were taken and correlated with appearances, clinical course, and biopsy findings. In burns in which the epithelium has been lost there is a clear gradient of surface temperature such that full-thickness burns are about $2^{\circ} \mathrm{C}$. lower than the normal surrounding skin and partial-thickness burns intermediate. Evaporation is of great importance in causing this lowering of surface temperature. In addition, damage to deep blood vessels tends to insulate the surface from the warming effects of the circulation, tonic contraction of the vessels plays a part, and there may be other more subtle differences due to changes in the movement of fluids in the tissues.

Choice of a method of diagnosis depends on reliability, convenience, and freedom from disadvantages. The pinprick test, dye methods, and temperature determinations all give reliable results within their defined limits. For convenience the pin-prick test is possibly the most acceptable, since sterile needles are usually available. Special supplies of intravenous materials are needed for the dye techniques, and, in the case of the fluorescent methods, facilities also for viewing in ultra-violet light. For temperature measurements Forage used an electrical skin thermometer of good quality. A disadvantage of the pin-prick test is that it may add to the patient's apprehension, and children particularly may fail to co-operate. The dyes visible in ordinary light have the serious disadvantage of causing large areas of staining, which may be embarrassing to both the patient and his friends, but staining usually disappears in 24 to 48 hours. Provided the skin thermometer probe is sterile there seem to be few disadvantages to the surface-temperature method apart from the fairly elaborate techniques of measurement and recording needed. Up to the present it has chiefly been used for research. Developments of apparatus might simplify the procedure, and we look forward to further evidence of its range of application.

1 Bull, J. P., and Squire, J. R., Ann. Surg., 1949, 130, 160.

2 Artz, C. P., and Reiss, E., Treatment of Burns, 1957, Saunders.

${ }^{3}$ Davies, J. W. L., and Topley, E., Clin. Sci., 1956, 15, 135.

4 Jackson, D. M., Brit. F. Surg., 1953, 40, 588.

is Brit. med. F., 1961, 2, 1766.

- Dupuytren, G., Lecons Orales de Clinique Chirurgicale, 1832, 1, 413. Paris.

Cope, O., Langohr, J. L., Moore, F. D., and Webster, R. C., Amn. Surg.,

8 Bull, J. P., and Lennard-Jones, J. E., Clin. Sci., 1949, 8, 155.

- Sevitt, S., F. Path. Bact., 1949, 61, 427.

10 Gibson, T., and Brown, A., Spec. Rep. Ser. med. Res. Coun. (Lond.), 1945, No. 249 , p. 51.

11 Tempest, M. N., Trans. Ass. industr. med. Offr., 1961, 11, 22.

18 Dingwall, J. A., Ann. Surg., 1943, 118, 427.

13 Forage, A. V., 1960, M.Ch. Thesis, University of Liverpool.

14 —_ Ann. roy. Coll. Surg. Engl., 1964, 35, 341.

\section{Hallux Valgus}

In Great Britain hallux valgus develops in childhood, increases in incidence with age in both sexes, but more rapidly in girls from the age of 7 years. It tends to be a progressive deformity, frequently resulting in the formation of bunions, and it is a common cause of pain in the foot in middle-aged women.

Many causes have been suggested. N. C. Lake ${ }^{1}$ thought that there was an evolutionary weakness of the foot that resulted in splay foot with secondary lateral displacement of the big toe by the toe-cap of the shoe. W. Truslow ${ }^{2}$ thought that the inheritance of a wide angle between the first and second metatarsals predisposed to hallux valgus. But R. H. Hardy and J. C. R. Clapham ${ }^{3}$ found that the deformity actually preceded the widening of the first intermetatarsal angle, so that congenital widening of this angle could have only a secondary role. R. W. Haines and A. McDougall, using an experimental sandal, found that the foot slides forward on walking and produces a "wedging" effect of the toes in the front of the shoe, unless this forward thrust is taken by a strap across the instep. They concluded that all women's low-cut fashionable shoes must deform the foot by forcing the big toe into the valgus position.

Nevertheless occasionally severe hallux valgus does affect the feet of people who habitually go unshod, ${ }^{5}$ though this might be due to trauma and subsequent arthritis. Studying the mean hallux angle (a measure of the deviation of the big toe in relation to the long axis of the foot) N. A. Barnicot and R. H. Hardy found a value of $+0.24^{\circ}$ in unshod Nigerian women and $+1.88^{\circ}$ in unshod men, compared with $+6.9^{\circ}$ and $+11^{\circ}$ in male and female Europeans. B. Kalcev ${ }^{\circ}$ in his study of unshod feet in Madagascar found that the mean hallux angle changed from $-0.64^{\circ}$ at 6 years to $+2.52^{\circ}$ at 15 years, but did not increase after this age.

At p. 1648 of this week's B.M.F. Dr. I. B. Shine reports his findings in St. Helena. He examined the feet of 3,315 islanders, who were divided into two groups-the barefoot and the shoe-wearers. The latter were further subdivided according to the length of time the shoes had been worn. His results show that the longer shoes were worn the greater the incidence of a mean hallux angle of $15^{\circ}$ and over. Thus in the unshod the incidence of hallux valgus was under $2 \%$, but in men who had worn shoes for sixty years it was $16 \%$ and in women $48 \%$. The association of hallux valgus and shoe-wearing was found to be highly significant, whereas social class, occupation, or exercise was not.

Surveys in Britain of schoolchildren's feet have shown an association between hallux valgus and ill-fitting shoes. ${ }^{7}$ In Ealing it was found that the use of well-fitting shoes alone lessened the degree of hallux valgus in children, and similar results have been found in adults. ${ }^{8}$

Hence there are two main components in the development of hallux valgus. The first is the minor degree that occurs naturally in unshod feet with age, and the second is the major degree that is associated with wearing shoes. Well-fitting shoes are therefore of paramount importance to avoid severe hallux valgus and the formation of bunions. ${ }^{9}$

\footnotetext{
Lake, N. C., The Foot, 1952, 4th ed. Baillière, Tindall and Cox, London.

Truslow, W., f. Bone ft Surg., 1925, 7, 98.

Hardy, R. H., and Clapham, J. C. R., Lancet, 1952, 1, 1180.

Haines, R. W., and McDougall, A., ibid., 1954, 2, 1308

3 Barnicot, N. A., and Hardy, R. H., 7. Anat. (Lond.), 1955, 89, 355.

- Kalcev, B., E. Afr. med. Э., 1963, 40, 47.

' Craigmile, D. A., Brit. med. Ұ., 1953, 2, 749.

Burry, H. S., Brit. Boot, Shoe, and Allied Trades Res. Ass. Res. Rep.

No. 147.

- Brit. med. F., 1964, 2, 1282.
} 